\title{
Incidence of Clostridium perfringens in Broiler Chickens in the Czech Republic
}

\author{
I. SVOBODOVÁ, I. STEINHAUSEROVÁ, M. NEBOLA
}

Department of Meat Hygiene and Technology, Faculty of Veterinary Hygiene and Ecology, University of Veterinary and Pharmaceutical Sciences Brno, Czech Republic

Received June 4, 2007

Accepted October 2, 2007

\begin{abstract}
Svobodová I., I. Steinhauserová, M. Nebola: Incidence of Clostridium perfringens in Broiler Chicken in the Czech Republic. Acta Vet. Brno 2007, 76: S25-S30.

Clostridium perfringens is a causative agent of human and animal foodborne diseases. It is known as a normal inhabitant of the intestinal tract of chickens as well as a potential pathogen causing necrotic enteritis. The aim of the present study was to detect the incidence of $C$. perfringens in healthy broiler chickens. From May 2005 to September 2006, 609 samples of caecal content from broilers from 23 intensive poultry farms were analyzed. The samples were cultivated on TSC and blood agar, typical colonies were identified and biochemically confirmed. The total number of positive samples was $112(18.39 \%)$. The samples were processed by the multiplex polymerase chain reaction method (PCR) for toxin genotyping. The presence of alpha, beta, beta 2 and enterotoxin gene was detected. All C. perfringens isolates were classified as type A, four isolates had the $c p b 2$ gene. In conclusion the prevalence of $C$. perfringens-positive farms is approximately $74 \%$ and the amount ranges about $10^{4} \mathrm{cfu} / \mathrm{g}$ of caecal content.
\end{abstract}

Clostridium, necrotic enteritis, PCR, occurrence

Clostridium perfringens is a widespread spore-forming, Gram-positive, anaerobic, nonmotile rod. It is recognized as an enteritic bacterial pathogen in humans, poultry, other farm animals and wildlife worldwide (Songer 1996; Craven et al. 2003). It is often found in the intestinal tract of healthy birds but it can cause necrotic enteritis (NE) in many species of poultry and especially in broiler and turkey flocks (Engström et al. 2003). At low population levels $\left(<10^{4} \mathrm{cfu}\right)$ the organism is non-pathogenic. The pathogenicity of the organism is associated with several toxins. C. perfringens is usually classified into five types (A - E) on the basis of its ability to produce the major lethal toxins $\alpha, \beta, \varepsilon$ and 1 (Yoo et al. 1997) and according to specific animal hosts. Only $C$. perfringens types $\mathrm{A}$ and $\mathrm{C}$ are pathogenic for poultry. However, the presence of $C$. perfringens does not lead directly to the disease. Although 75 - 95\% of birds are colonised by C. perfringens, only a small proportion of these ever shows symptoms of the disease (McDevitt et al. 2006). The disease in poultry is called necrotic enteritis and is presented in an acute or subclinical form. The acute form leads to increased mortality in the last weeks of the rearing period. Typical clinical signs include depression, dehydration, somnolence, ruffled feathers, diarrhoea and decreased feed consumption. The subclinical form is characterized by damage to the intestinal mucosa that decreases digestion, absorption and reduces weight gains. Subclinical C. perfringens infection is also associated with hepatitis and cholangiohepatitis. The gut epithelial damage associated with NE coincides with infection by the coccidian genus Eimeria, and so NE and coccidiosis are often linked as one set of similar symptoms (Williams 2005).

Toxins: The major lethal effects associated with $\alpha$-toxin are necrotic enteritis and enterotoxemia in animals (Siragusa et al. 2006). $\alpha$-toxin (phospholipase C) is commonly produced by all 5 types. It can hydrolyze lecithin into phosphorylcholine and diglyceride, which leads to tissue damage. $\beta$-toxin is produced by $C$. perfringens type $\mathrm{B}$ and type $\mathrm{C}$ strains and it causes a necrotic enteritis characterized by haemorrhagic mucosal ulceration

Address for correspondence:

I. Svobodová

Department of Meat Hygiene and Technology

University of Veterinary and Pharmaceutical Sciences

Palackého 1-3, 61242 Brno, Czech Republic

Phone: + 420541562746

Fax: +420541321 230

E-mail: svobodovai@vfu

http://www.vfu.cz/acta-vet/actavet.htm 
or superficial mucosal necrosis of the small intestine in animals (types B and C) (Smedley III. et al. 2004). Toxins $\varepsilon$ and $ı$ play no role in pathogenesis in poultry diseases. C. perfringens produces many minor toxins, but the most important are $\beta 2$-toxin and enterotoxin. The $\beta 2-$ toxin was first cloned and sequenced by Gibert et al. in 1997 (Gibert et al. 1997; Schotte et al. 2004). Despite its name, $\beta 2$-toxin has no significant amino acid similarity with $\beta$ toxin. Detailed studies of the mechanism of action of $\beta 2$-toxin have not been performed and published yet (Smedley III. et al. 2004). Its biological activity is comparable with that of the $\beta$-toxin (Schotte et al. 2004). The $\beta 2$-toxin has also been demonstrated in avian $C$. perfringens type A strains, but its exact role in pathogenesis needs to be further elucidated. All types of $C$. perfringens can produce enterotoxin that is responsible for provoking disease in both man and animals (Van Immerseel et al. 2004). Enterotoxin relates to food poisoning and is produced during sporulation in the infected host intestine, where it binds to the intestinal epithelium, forms pores and causes diarrhoea (Nakamura et al. 2004).

In the Czech Republic no monitoring of $C$. perfringens incidence in poultry is conducted. The aim of the present study was to detect the incidence of $C$. perfringens in healthy broiler chickens from farms with intensive rearing technology and partial zoohygiene monitoring. The next aim was to find out whether the incidence of $C$. perfringens in the alimentary tract increased comparing years 2005 and 2006.

\section{Materials and Methods}

\section{Profiles of farms}

In the Czech Republic there is a preponderance of farms with intensive rearing technology. The length of rearing periode between 34 - 37 days, deep litter of straw, commercial pelleted feed mix and all-in-all-out technology are typical for these farms. The feed mix contained coccidiostats. Production unit number ranges from 35000 to 275000 birds in farm. In all farms were used only two broiler lines: Cobb 500 and Ross 308.

\section{Sample collection}

Samples were collected from 23 intensive poultry farms in the period from June 2005 to September 2006. Eight farms were investigated in 2005 and 15 farms in 2006. Samples from farms coded 5 - 42 (Table 1) were collected in the slaughterhouse after veterinary inspection. Contents of gastrointestinal tracts were placed into sterile plastic bags and immediately transported to the laboratory. Samples from farms coded 43,44 and 45 were obtained directly at the farm, where broilers were slaughtered there and then transported to the laboratory. Poultry carcasses were eviscerated to obtain the gastrointestinal tract. On each farm, a sample of litter, feed from the feeding trough and water from the drinking trough were collected for environmental and zoohygienic parameters monitoring purposes.

\section{Preparation}

Five grams of sterile caecal intestinal content obtained were added to $45 \mathrm{ml}$ of saline solution and thoroughly mixed by Stomacher. The samples were then diluted with saline solution to the final concentration of $1: 1000$. All samples of litter, feed and water were processed likewise, water samples were left undiluted, while litter and feed samples were diluted to the final concentration of $1: 100$.

\section{Microbiological methods}

Samples of $1 \mathrm{ml}$ of the final suspension ( $1 \mathrm{ml}$ of water) were placed into the Petri dishes and overlaid with tryptose-sulphite-cycloserine (TSC) agar (Oxoid, Basingstoke, UK), with Perfringens Selective Supplement (Oxoid, Basingstoke, UK) and without egg yolk emulsion. The samples were incubated for $22 \pm 2 \mathrm{~h}$ at $37^{\circ} \mathrm{C}$. After incubation, typical black colonies were counted and selected for cultivation on blood agar (Oxoid, Basingstoke, UK) with 5\% defibrinated sheep blood (Bioveta, Ivanovice na H., CZ). All incubations were conducted under anaerobic conditions using the AnaeroGen Atmosphere Generation System (Oxoid, Basingstoke, UK). Isolated colonies with a typical double zone of haemolysis were then biochemically tested. The commercial available test kit ANAERO test $23^{\circledR}$ (Pliva-Lachema, Brno, CZ) was used for the tests. All isolated strains were stored in a cooked meat medium (Oxoid, Basingstoke, UK) at $-70^{\circ} \mathrm{C}$ for subsequent toxin genotyping.

DNA isolation

DNA was isolated using DNeasy ${ }^{\circledR}$ Tissue kit (Qiagen, Germany) according to the manufacturer's instructions.

\section{Multiplex PCR}

The type (A or C) and presence of the enterotoxin gene (cpe) and the $\beta 2$-toxin (cpb2) gene of each C.perfringens isolate were determined by a modified version of the multiplex PCR assay (Baums et al. 2004). $2 \mu 1$ template DNA was added to a $25 \mu \mathrm{l}$ reaction mixture with the following reagents: $10 \mu \mathrm{l}$ of PPP master mix (PPP Master 
Table 1. Incidence of $C$. perfringens in caecal content and the results of toxinotyping

\begin{tabular}{|c|c|c|c|c|c|c|}
\hline $\begin{array}{l}\text { Code } \\
\text { of farm }\end{array}$ & $\begin{array}{l}\text { Year of sampling/ } \\
\text { broiler line }\end{array}$ & $\begin{array}{l}\text { No. of samples } \\
\text { (N) }\end{array}$ & $\begin{array}{l}\text { No. of positive } \\
\text { samples }(\mathrm{N}+)\end{array}$ & $\begin{array}{l}\text { No. of positive } \\
\text { samples }(\mathrm{N}+) \%\end{array}$ & $\mathrm{CFU} / \mathrm{G}$ & Type \\
\hline 5 & 2006 / Ross 308 & 30 & 2 & 6.67 & $4.5 \cdot 10^{3}$ & $2 \mathrm{~A} c p b 2$ \\
\hline 6 & $2006 /$ Ross 308 & 20 & 0 & 0 & - & - \\
\hline 7 & $2005 /$ Cobb 500 & 36 & 0 & 0 & - & - \\
\hline 8 & $2005 /$ Cobb 500 & 25 & 14 & 56.00 & $<10^{4}$ & $14 \mathrm{~A}$ \\
\hline 9 & $2005 /$ Cobb 500 & 29 & 2 & 6.90 & $<10^{4}$ & $2 \mathrm{~A}$ \\
\hline 11 & 2005 / Ross 308 & 30 & 0 & 0 & - & - \\
\hline 13 & $2005 /$ Cobb 500 & 30 & 0 & 0 & - & - \\
\hline 14 & $2006 /$ Cobb 500 & 30 & 11 & 36.67 & $2.1 .10^{5}$ & $11 \mathrm{~A}$ \\
\hline 15 & 2006 / Ross 308 & 31 & 15 & 48.39 & $2.6 .10^{5}$ & $15 \mathrm{~A}$ \\
\hline 16 & $2006 /$ Cobb 500 & 15 & 6 & 40.00 & $2.8 \cdot 10^{4}$ & $6 \mathrm{~A}$ \\
\hline 18 & $2006 /$ Cobb 500 & 20 & 1 & 5.00 & $1.10^{3}$ & $1 \mathrm{~A}$ \\
\hline 19 & $2005 /$ Cobb 500 & 29 & 18 & 62.07 & $<10^{4}$ & $18 \mathrm{~A}$ \\
\hline 20 & 2006 / Ross 308 & 30 & 8 & 26.67 & $7.8 .10^{4}$ & $8 \mathrm{~A}$ \\
\hline 21 & $2006 /$ Cobb 500 & 30 & 9 & 30.00 & $2.4 .10^{4}$ & $9 \mathrm{~A}$ \\
\hline 22 & $2006 /$ Cobb 500 & 30 & 2 & 6.67 & $3.10^{5}$ & $2 \mathrm{~A}$ \\
\hline 33 & 2006 / Ross 308 & 15 & 1 & 6.67 & $1.10^{3}$ & $1 \mathrm{~A}$ \\
\hline 36 & $2006 /$ Cobb 500 & 29 & 15 & 51.72 & $1.2 .10^{4}$ & $15 \mathrm{~A}$ \\
\hline 40 & 2005 / Ross 308 & 30 & 0 & 0 & - & - \\
\hline 41 & 2005 / Ross 500 & 30 & 0 & 0 & - & - \\
\hline 42 & $2006 /$ Cobb 500 & 30 & 2 & 6.67 & $1.5 .10^{5}$ & $2 \mathrm{~A}$ \\
\hline 43 & $2006 /$ Ross 308 & 20 & 1 & 5.00 & $3.10^{4}$ & $1 \mathrm{~A}$ \\
\hline 44 & $2006 /$ Ross 308 & 20 & 2 & 10.00 & $1.5 .10^{4}$ & $1 \mathrm{~A} ; 1 \mathrm{Acpb2}$ \\
\hline 45 & 2006 / Ross 308 & 20 & 3 & 15.00 & $3.10^{4}$ & $2 \mathrm{~A} ; 1 \mathrm{~A} c p b 2$ \\
\hline 23 farms & - & 609 & 112 & 18.39 & - & $108 \mathrm{~A} ; 4 \mathrm{~A} c p b 2$ \\
\hline
\end{tabular}

mix, Top-Bio, CZ), $2 \mu \mathrm{l}$ of the mixture of primers (200 nM CPA5L, $200 \mathrm{nM}$ CPA5R; $138 \mathrm{nM}$ CPBL, $138 \mathrm{nM}$ CPBR; 67 nM CPEL, 67 nM CPER; 117 nM CPB2L, 117 nM CPB2R) and $11 \mu 1$ distilled water. Primers for $\varepsilon$ - and l-toxins were not used, because these toxins belong to the types B, D and E (Table 2).

Table 2. Oligonucleotide sequences of the primers used

\begin{tabular}{|l|l|l|c|}
\hline Toxin/gene & Primers & Oligonucleotide sequence $\left(5^{\circ}{ }^{\circ}{ }^{\circ}\right)$ & Fragment lenght (bp) \\
\hline$\alpha / c p a$ & CPA5L & AGTCTACGCTTGGGATGGAA & 900 \\
\hline & CPA5R & TTTCCTGGGTTGTCCATTTC & 611 \\
\hline$\beta / c p b$ & CPBL & TCCTTTCTTGAGGGAGGATAAA & 200 \\
\hline$\beta 2 / c p b 2$ & CPBR & TGAACCTCCTATTTTGTATCCCA & \\
\hline & CPB2L & CAAGCAATTGGGGGAGTTTA & 506 \\
\hline Enterotoxin/cpe & CPB2R & GCAGAATCAGGATTTTGACCA & \\
\hline & CPER & ACCAGCTGGATTTGAGTTTAATG & \\
\hline
\end{tabular}

The multiplex PCR program was slightly modified. The reaction was performed in a Palm-cycler (Corbett Research, Australia) under the following conditions: initial denaturation at $95{ }^{\circ} \mathrm{C}$ for $3 \mathrm{~min}$; 35 cycles at 95 ${ }^{\circ} \mathrm{C}$ for $1 \mathrm{~min} ; 55^{\circ} \mathrm{C}$ for $1 \mathrm{~min} ; 72^{\circ} \mathrm{C}$ for $1 \mathrm{~min} 30 \mathrm{~s}$; final extension at $72^{\circ} \mathrm{C}$ for $2 \mathrm{~min} .5 \mu \mathrm{l}$ of the amplicons were separated on 2\% agarose gel (SERVA, Germany) and stained with ethidium bromide (SERVA, Germany). Standard DNA molecular weight marker (GeneRuler ${ }^{\mathrm{TM}} 100 \mathrm{bp}$ DNA Ladder, Fermentas, Canada) was used to indicate the size of amplification products.

Bacterial strains

The C. perfringens reference strains CIP 106640 (type C; $c p a, c p b, c p b 2$ genes; Collection de I'Institut Pasteur, 
Paris, France), NCTC 8237 (type A; cpa gene; Czech Collection of Microorganisms, Brno, CZ) NCTC 8238 (type A; cpa, cpe genes; Czech Collection of Microorganisms, Brno, CZ) CNCTC 57/70 (type C; cpa, cpb genes; SZU, Praha, CZ) were used as an internal control.

\section{Results and Discussion}

Between June 2005 and September 2006, a total of 609 caecum content samples from healthy broiler chickens from 23 farms were examined for the presence of $C$. perfringens. With $18.39 \%$ samples $(n=112)$ the cultivation was successful (Table 1$)$. In six of the 23 farms investigated, no $C$. perfringens in healthy poultry was found, which corresponds to the $73.91 \%$. perfringens prevalence on the farms. The monitoring of $C$. perfringens incidence on intensive and extensive broiler farms was also conducted in Italy (Manfreda et al. 2006). In his study 22 intensive farms (total of 99 samples examined) and 11 extensive broiler farms (total of 50 samples), were tested and the authors reported an overall prevalence of over $90 \%$. The pathogen was detected in 87 of the total of 149 samples $(58.40 \%)$. No statistically significant differences between intensive and extensive broiler farms were shown. The incidence in Italy seems to be higher than in the Czech Republic ( $>90$ vs. $73.91 \%$ ). The cultivation methods are similar, so the results are comparable.

By the PCR method all 112 isolated strains from our study were determined as type A and in four of them the presence of $c p b 2$ gene was demonstrated. The enterotoxin gene was detected in none of the samples tested (Table 1). Manfreda et al. (2006) reported that all strains belong to the type A, too. The author does not mention any enterotoxin gene or $c p b 2$ gene detection. Similar results have also been published by authors from other European countries. Heikinheimo and Korkeala (2005) from Finland reported the results of their tests of 118 poultry isolates using the multiplex PCR method: all the strains were classified as type A strains and, like in isolates obtained in the Czech Republic no enterotoxin-positive strain was found. The material was not tested for the presence of $c p b 2$ gene. Engström et al. (2003) from Sweden reported the presence of $c p b 2$ gene in only 2 of the total of 53 strains tested. All of the strains were classified as type A with no enterotoxin gene present. The most recent study from Belgium (Gholamiandekhordi et al. 2006) reports the presence of $c p b 2$ gene in 4 strains, and the presence of the enterotoxin gene in 2 strains of a total of 27 healthy broiler chickens examined. A comparison with our study shows an agreement in type classification. The above authors either used isolated strains or they do not give the numbers of tested samples and positive samples, thus making total prevalence comparisons impossible.

The quality of zoohygiene is attested by data given in Table 3. The incidence of $C$. perfringens in litter and water, which act as vectors for the spread of $C$. perfringens among individual animals was only demonstrated on one of the farms investigated. All the farms sanitize fattening premises between individual all-in-all-out production cycles, and the results obtained are therefore comparable.

Table 3. The incidence of $C$. perfringens in enviroment of farm coded 43, 44 and 45

\begin{tabular}{|c|c|c|c|}
\cline { 2 - 4 } \multicolumn{1}{c|}{} & \multicolumn{3}{c|}{ Farm code, amount and type of C. perfringens } \\
\hline Sample type & 43 & 44 & 45 \\
\hline Water & - & - & type A; $c p b 2 \mathrm{gene} ; 1,2.10^{2} \mathrm{cfu} / \mathrm{ml}$ \\
\hline Litter & - & - & type A; $1,5.10^{4} \mathrm{cfu} / \mathrm{g}$ \\
\hline Feed & - & - & - \\
\hline
\end{tabular}

Monitoring during two years enables comparison of incidence in a longer time period, too. Thirty-four strains (14.2\%) of C. perfringens were isolated from a total of 239 intestines examined in the Czech Republic in 2005. In 2006, 370 intestines were examined and 78 strains $(21.1 \%)$ were isolated. The samples were negative from 5 farms in 2005 , while 
in 2006 samples were negative only from one farm. This finding enables to say, that the prevalence on farms is rising. This fact can apparently relate to the phasing out of growpromoting antibiotics (GPA). Since January 2006 the use of previously approved growthpromoting antibiotics like flavophospholipol, monensin, salinomycin and avilamycin has been banned in chicken feed. The end to use of growth-promoting antibiotics in the Czech Republic manifested itself by deteriorated intestinal integrity, increased morbidity and it affected the overall production efficiency (Cviková et al. 2006). Unfortunately, there are no specific data about using GPA on the investigated farms, but it is known, that on all farms are still used ionophore coccidiostats.

For better illustration of the situation it would be better to monitor the number of cfu in the samples, but this monitoring was not the main target in this study. On the basis of the used dilution it is possible to estimate the number of $C$. perfringens like colonies per gram (Table 1). Only in four cases the value is higher than $10^{5} \mathrm{cfu} / \mathrm{g}$, in the other cases ranges the value between $10^{3}$ to $10^{4} \mathrm{cfu} / \mathrm{g}$ Manfreda (2006) reported the average value $4,5.10^{4} \mathrm{cfu} / \mathrm{g}$, with no significant differences between intensive and extensive broiler farm types.

It follows from the research that $C$. perfringens occurrence found in the Czech Republic is similar to the other European countries. Maintenance of intestinal integrity is a critical component of modern poultry management. An outbreak of a disease would entail serious economic losses for farmers and the incidence should therefore be closely monitored and great attention should be paid to zoohygiene and other preventive measures.

\section{Výskyt Clostridium perfringens u brojlerových kuřat v České republice}

Clostridium perfringens patří mezi známé původce onemocnění lidí i zvířat. U drůbeže způsobuje nekrotickou enteritidu představující vážný ekonomický problém. V období od května 2005 do konce záŕí 2006 bylo vyšetřeno celkem 609 vzorkủ obsahu slepých střev brojlerových kur̆at z 23 farem s intenzivním způsobem výkrmu. Vzorky byly kultivovány na TCS agaru a krevním agaru, typické kolnie byly dále konfirmovány biochemicky. Stanovení toxinových genů bylo provedeno multiplexní polymerázovou reakcí (multiplex-PCR). Celkový počet pozitivních vzorků byl 112, což je asi 18\%. Všechny izolované kmeny byly přiřazeny $\mathrm{k}$ typu $\mathrm{A}$, u dvou z nich byl detekován gen pro $\beta 2$ toxin.

\section{Acknowledgement}

We thank the members of PoultryFlorGut team for providing their results. Financial support was provided by PoultryFlorGut FOOD-CT-200X-007076 and the Ministry of Education, Youth and Sports of the Czech Republic No. 6215712402 .

\section{References}

BAUMS CG, SCHOTTE U, AMTSBERG G, GOETHE R 2004: Diagnostic multiplex PCR for toxin genotyping of Clostridium perfringens isolates. Vet Microbiol 100: 11-16

CRAVEN SE, COX NA, BAILEY JS, COSBY DE 2003: Incidence and tracking of Clostridium perfringens through an integrated broiler chicken operation. Avian Dis 47: 77-711

CVIKOVÁ I, PAPP IH 2006: Vyřazení antibiotických růstových stimulátorů, dopad na zdraví a užitkovost brojlerů. Veterinářství 10: 642-644

ENGSTRÖM BE, FERMÉR C, LINDBERG A, SAARINEN E, BÅVERUD V, GUNNARSSON A 2003: Molecular typing of isolates of Clostridium perfringens from healthy and diseased poultry. Vet Microbiol 94 : 225-235

GHOLAMIANDEKHORDI AR, DUCATELLE R, HEYNDRICKX M, HAESEBROUCK F, VAN IMMERSEEL F 2006: Molecular and phenotypical characterization of Clostridium perfringens isolates from poultry flocks with different disease status. Vet Microbiol 113: 143-152

GIBERT M, JOLIVET-REYNAUD C, POPOFF MR 1997: $\beta 2$ toxin, a novel toxin produced by Clostridium perfringens. Gene 203: 65-73

HEIKINHEIMO A, KORKEALA H 2005: Multiplex PCR assay for toxinotyping Clostridium perfringens isolates obtained from Finnish broiler chickens. Lett Appl Microbiol 40: 407-411 
MANFREDA G, BONDIOLI V, DE CESARE A, FRANCHINI A 2006: Quantitative evaluation of Clostridium perfringens in Italian broilers. Poult Sci 62 (Suppl): 91-92

MCDEVITT RM, BROOKER JD, ACAMOVIC T, SPARKS NHC 2006: Necrotic enteritis; a continuing challenge for the poultry industry. Poult Sci 62: 221-247

NAKAMURA M, KATO A, TANAKA D, GYOBU Y, HIGAKI S, KARASAWA T, YAMAGISHI T 2004: PCR identification of the plasmid-borne gene (cpe) in Clostridium perfringens strains isolated from food poisoning outbreaks. Int J Med Microbiol 294: 261-265

SCHOTTE U, TRUYEN U, NEUBAUER H 2004: Significance of $\beta 2$-Toxigenic Clostridium perfringens infection in animals and their predisposing factors-a review. J Vet Med B 51: 423-426

SIRAGUSA GR, DANYLUK MD, HIETT KL, WISE MG, CRAVEN SE 2006: Molecular subtyping of poultryassociated type A Clostridium perfringens isolates by repetitive-element PCR. J Clin Microbiol 44: 10651073

SMEDLEY III JG, FISHER DJ, SAYEED S, CHAKRABARTI G, MCCLANE BA 2004: The enteric toxins of Clostridium perfringens. Rev Physiol Biochem Pharmacol 152: 183-204

SONGER JG 1996: Clostridial enteritic diseases of domestic animals. Clin Microbiol Rev 9: 216-234

VAN IMMERSEEL F, DE BUCK J, PASMANS F, HUYGHEBAERT G, HAESEBROUCK F, DUCATELLE R 2004: Clostridium perfringens in poultry: an emerging threat for animal and public health. Avian Pathol 33: 537-549

WILLIAMS RB 2005: Intercurrent coccidiosis and necrotic enteritis of chickens; rational, integrated disease management by maintenance of gut integrity. Avian Pathol 34: 159-180

YOO HS, LEE SU, PARK KY 1997: Molecular typing and epidemiology survey of prevalence of Clostridium perfringens types by multiplex PCR. J Clin Microbiol 35: 228-232 